\title{
Estudio comparativo experimental del comportamiento de uniones de cumbrera en cubiertas de madera laminada encolada con placas interiores de acero o tablero contrachapado de abedul
}

\section{Experimental study comparing the behaviour of steel truss plates and birch plywood inserts in ridge joints on glued laminated rafters}

\author{
M. A. Serrano López ${ }^{(*)}$, A. G. Lozano Martínez-Luengas(*), F. López Gayarre(*), J. J. Del Coz Díaz(*)
}

Recepción/Received: 31-X-07

Aceptación/Accepted: 27-IV-08

Publicado online/Online publishing: 27-VII-09

RESUMEN

El presente trabajo tiene por objeto llevar a cabo un análisis experimental del comportamiento mecánico de ciertos sistemas planos de unión para elementos estructurales de madera laminada empleados en la construcción de cubiertas

El estudio incluye los ensayos a escala real de seis din-teles a dos aguas de madera laminada, de $6 \mathrm{~m}$ de luz, $1 \mathrm{~m}$ de altura y una sección de $100 \mathrm{~mm}$ x $180 \mathrm{~mm}$, sometidos a flexión en cuatro puntos. En tres dinteles el elemento de unión es una pieza de tablero contra-chapado de abedul, mientras que en los otros tres se ha utilizado un herraje de acero. La finalidad es valorar la posibilidad de sustituir los elementos de unión, realizados mediante herrajes, por otros constituidos por piezas de tablero contrachapado de abedul. Este objetivo se logra comparando el comportamiento resistente mostrado por ambos dispositivos de unión, y las deformaciones en cada caso de las estructuras completas.

Los resultados resultaron muy satisfactorios tanto en la capacidad portante como en la rigidez de los dinteles.

Palabras clave: madera laminada, uniones mecánicas, herrajes, tablero contrachapado, resistencia a flexión.
SUMMARY

The present paper reports on an analysis of the mechanical performance of two flat joining systems used in roof members made of glued laminated timber.

Six pairs of laminated timber rafters for a double-pitched roof with a $100 \times 180-\mathrm{mm}$ cross-section, a $6.00-\mathrm{m}$ span and a height of $1.00 \mathrm{~m}$ were subjected to full-scale four-point bending. In three of the specimens the rafters were joined at the ridge with a birch plywood insert, while in the other three the connection was secured with a fitting consisting in a standard flat steel truss plate. The objective pursued was to evaluate the possibility of replacing the steel fittings with birch plywood inserts. The approach adopted to reach this objective was to compare the strength of the two joint pieces and the deformation generated in the overall structure during strength tests.

The results proved to be highly satisfactory in terms of both the bearing capacity and the stiffness of the structures tested.

Keywords: laminated timber, mechanical joints, steel fittings, plywood, flexural strenght.

(*) Universidad de Oviedo (Oviedo, España). 


\section{INTRODUCCIÓN}

El sector de la construcción es responsable de un porcentaje muy elevado del consumo energético y de la utilización de los recursos naturales disponibles. Teniendo en cuenta el ritmo de crecimiento presente, la sostenibilidad del proceso constructivo, desde el punto de vista de la fabricación de materiales, su puesta en obra, la eliminación de los residuos y su ciclo de vida, resulta un objetivo fundamental, y como tal debería tenerse presente en la redacción de cualquier estudio o proyecto de última generación. Su valoración global parte de una visión equilibrada de los tres aspectos fundamentales: el impacto sobre el medio ambiente, la repercusión social y su sostenibilidad económica.

En lo que respecta exclusivamente a los componentes estructurales, resulta obvio que la madera es el material que implica el menor impacto medioambiental, especialmente si está bien gestionada, de acuerdo a los indicadores de gestión sostenible de alguno de los sistemas de certificación existentes (FSC-Forest Stewardship Council, PEFC, etc.).

Las ventajas que implica utilizar la madera en la construcción son de sobra conocidas (1), por lo que su empleo en edificación y obra civil resulta cada vez más significativo; y muy especialmente en el caso de elementos de cubierta ya que, al margen de las ventajas estéticas, resulta evidente que el menor peso de los faldones conlleva una menor transferencia de carga a la estructura y a la cimentación (2).

El proceso general de construcción de componentes estructurales en madera exige la utilización de elementos de unión entre las diferentes piezas. Dada la homogeneidad en cuanto a los tipos de materiales de cobertura habitualmente empleados (fibrocemento, tejas, pizarras, chapa plegada, etc.) y a los sistemas constructivos que los reciben, los citados elementos de unión, conocidos como herrajes, se fabrican de manera industrializada. Así, las firmas comerciales, disponen en sus catálogos de diferentes soluciones constructivas para resolver los diversos tipos de nudos que pueden presentarse. Únicamente para aquellos casos en los que las sobrecargas sean muy elevadas, el cálculo deberá realizarse de manera particularizada. Sin embargo, la geometría suele ser la misma que para la situación anterior. Ciñéndonos a los componentes de cubierta (pares, cuchillos, cerchas), los sistemas industrializados de unión más usualmente empleados son las pletinas, conectores en $\mathrm{L}$, en $\mathrm{T}$ y las placas-clavo.

Asimismo, en la construcción tradicional, además de los diversos tipos de empalmes, ensambles y acoplamientos utilizados desde los primeros tiempos de la carpintería

\section{INTRODUCTION}

The construction industry consumes a sizeable share of the world's energy and available natural resources. In light of present growth rates, construction sustainability is an objective of vital importance that calls for action in all the areas involved: material manufacture, site assembly, and waste elimination and life cycle. As such, it should be present in any construction study or project drafted today, which should be evaluated in this regard on the grounds of a balanced vision of three key considerations, namely environmental impact, social consequences and economic sustainability.

As far as structural components are concerned, wood is obviously the material with the lowest environmental impact, particularly if the resource is well managed in terms of the sustainable management indicators defined in any of the existing certification systems (FSC -Forest Stewardship Council, PEFC and so on).

The advantages of using timber in construction are widely known (1) and its use in building and civil works is increasingly significant. It is particularly appropriate in roof members for, irrespective of the aesthetic advantages, the lighter the weight of a roof, the smaller is the load on the building structure and foundations (2).

Standard construction with structural timber necessitates the use of truss plates to secure the joints between members. Because the roofing materials generally used (fibrecement, roof tiles, slate, corrugated sheet steel and so forth) and the construction systems receiving them are highly standardized, these steel fittings, known as truss plates, are mass produced. Vendors list a number of construction solutions in their catalogues designed for different types of joints. These fittings need only be individually engineered in the event of very large live loads. And even in such cases, the geometry is generally the same as in standard situations. The industrialized systems most commonly used in roof members (rafters, trusses) include flatbars, L-connector brackets, tees and nailplates.

Moreover, in traditional construction the junctions, assemblies and couplings used since the advent of structural joinery are sometimes supplemented with 
estructural, en ocasiones también suelen complementarse con elementos de forja, con el fin de reforzar los encuentros entre los distintos elementos de las formas de cubierta. Al tratarse de elementos metálicos, presentan dos inconvenientes ciertamente importantes: la posibilidad de corrosión $y$, sobre todo, la baja resistencia frente al fuego. Efectivamente, en muchas ocasiones, el colapso de las estructuras leñosas, en una situación de incendio, no sobreviene por la carbonización del propio material componente de la estructura, sino por el fallo en los elementos metálicos que sirven de unión.

Al margen de estas consideraciones, en lo que respecta al proceso industrial de construcción de las cerchas y otros componentes de cubierta, tanto si están constituidas por madera maciza o laminada encolada, la materialización de las uniones con placas de acero interiores requiere las siguientes operaciones:

1) Cajeado de la escuadría de madera mediante un útil de corte conocido como "espada".

2) Marcado y apertura de taladros con la broca de madera.

3) Introducción de la pieza metálica de unión y marcado de los puntos a taladrar.

4) Extracción de la pieza metálica de unión y apertura de taladros con broca para metales.

5) Introducción de la pieza taladrada en la caja y presentación del elemento de cubierta.

6) Atornillado del conjunto.

Cuando la fabricación en serie alcanza un volumen de producción importante, este proceso es demasiado complejo, al tiempo que susceptible de que se produzcan errores y excentricidades entre los taladros practicados en las secciones de madera y los abiertos en las piezas metálicas.

Con el doble objetivo de acortar los periodos de fabricación de elementos de cubierta y mejorar su comportamiento frente al fuego, se propuso un novedoso sistema de conexión, basado en la modificación del material base componente de los herrajes. En esencia, se trataba de sustituir el herraje metálico fabricado en acero S275 $\mathrm{J0}$ por una pieza de geometría similar realizada a partir de tablero contrachapado de abedul (Figura 1). En esta línea, otros autores han realizado estudios experimentales similares (3-4).

Este derivado de la madera puede alcanzar características mecánicas superiores incluso al propio material base (5). Además, el empleo de estas piezas de contrachapado facilita una mayor precisión en la construcción del elemento de cubierta, consigue que desaparezcan los problemas derivados de la humedad por condensación en las pletinas metálicas y permite al fabricante de la estructura de madera una independencia frente a las empresas que comercializan los herrajes metálicos, lo que implica una disminución del precio final de la pieza. metallic elements to reinforce the joints between the roof members. The two major drawbacks to using such elements are possible corrosion and low fire resistance. Indeed, when fire breaks out in wood structures, the cause of collapse is often not the carbonization of the material itself, but the failure of the steel truss plates.

Irrespective of such considerations, in the industrial construction of wood trusses and other roof components, whether they are made of solid or glued laminated timber, joining members with internal steel truss plates entails the following operations:

\section{1) The timber is grooved with a wood chisel.}

2) Drill holes are marked and drilled with a wood bit.

3) The steel truss plate is set into position and the drill points marked.

4) The plate is withdrawn and the holes are drilled with a metal bit.

5) The holes in the steel truss plate are matched to the holes in the timber.

6) The plate is screwed to the timber.

For high volume series manufacture, this process is overly complex and prone to error and eccentricity in the drill holes in the timber and truss plates.

With the dual aim of shortening roof element manufacture time and improving fire resistance, a novel connection system was proposed based on changing the base material used for the fittings. In essence, the idea was to replace the fittings made of S275 $\mathrm{J0}$ steel with an insert with a similar geometry made of birch plywood (Figure 1). Other authors have been conducting experimental studies along this same line (3-4).

This wood product exhibits the same or even greater mechanical strength than the base material (5). In addition, the use of these plywood inserts allows more precise assembly of the roof member, eliminates the problems stemming from condensation damp on steel flatbars and affords timber structure manufacturers greater independence from steel fitting manufacturers, lowering the final cost. 


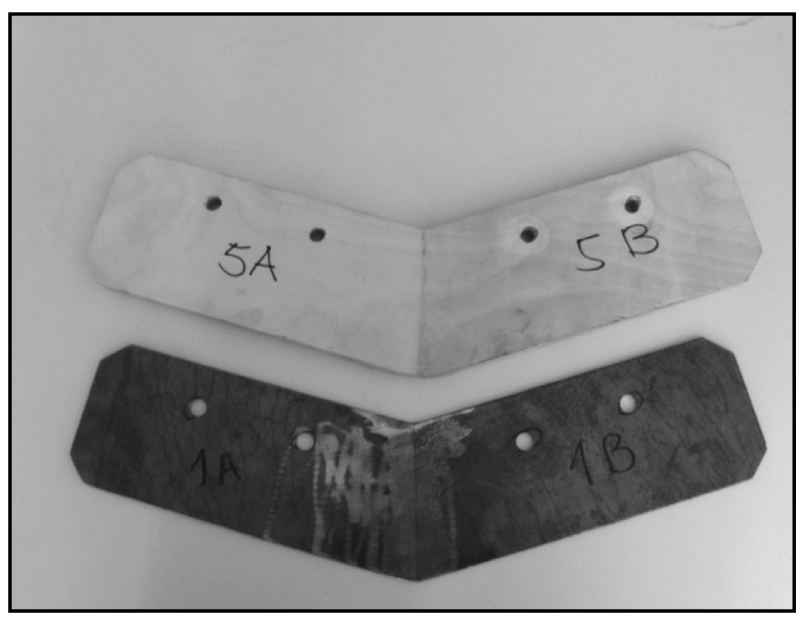

Figura 1. Pieza de unión de contrachapado de abedul y herraje metálico. Figure 1. Birch plywood insert and steel truss plate.

Para proteger la invención, se solicitó la patente correspondiente, por parte de los investigadores que la desarrollaron, con el número P200503182. Sin embargo, el desarrollo de esta invención planteaba una serie de inconvenientes importantes, relacionados a su vez entre sí:

a) Ausencia de datos fiables sobre el comportamiento del tablero contrachapado como material constituyente de la pieza de unión que se pretendía sustituir.

b) Necesidad de ensayar piezas a escala real, teniendo en cuenta la dificultad de materializar la fijación del elemento de conexión, las interacciones y esfuerzos a los que van a estar sometidos los pares y la pieza de unión, y especialmente los importantes desplazamientos que sufriría el conjunto.

c) Dificultad de localizar un equipo adecuado (bancada, actuadores y equipos de control y medida) que permitiera ejecutar los ensayos sobre piezas de $6 \mathrm{~m}$ de luz con un gálibo superior a $1 \mathrm{~m}$.

\section{PARTE EXPERIMENTAL}

\subsection{Descripción de la estructura ensayada}

Siguiendo las indicaciones del fabricante de la estructura, se trabajó con unos elementos de cubierta a dos aguas con una inclinación de $18^{\circ}$, una luz de $6 \mathrm{~m}$ y un gálibo máximo próximo a $1 \mathrm{~m}$, pensado para ser dispuestos en la cubierta con una separación entre pórticos de $3 \mathrm{~m}$. Cada dintel estaba formado por dos pares de madera laminada encolada de coníferas (Pinus Sylvestris, L.) de clase resistente GL24h con sección transversal rectangular de 100×180 mm, constituida por cuatro láminas de $45 \mathrm{~mm}$ de espesor, unidas entre sí mediante un empalme con unión dentada, con las médulas de sus láminas perimetrales de cada borde orientadas hacia el exterior.
The respective patent has been applied for under number P200503182 to protect the invention for the researchers working on its development, in which a series of important inter-related difficulties arose, including:

a) A lack of reliable data on the performance plywood, the constituent material of the insert intended to replace truss plates.

b) The need to test full-scale members, given the difficulty involved in fitting these connection brackets, the interactions and forces to which they and the rafters are subject and especially, the significant movement in the member as a whole.

c) The need for appropriate testing equipment (test bench, actuators and control and measuring instruments) for members with a 6- $m$ span and a clearance of over one metre.

\section{EXPERIMENTAL}

\subsection{Description of the structure tested}

Further to manufacturer instructions, the tests were conducted on two-pitch roof members with a slope of $18^{\circ}$, a 6- $m$ span and a clearance of around one metre, designed to rest on portal frames spaced at 3-m intervals. Each pair of rafters was made from GL24h glued laminated pine (Pinus sylvestris, L.) timber with a 100x180-mm cross section. Each timber comprised four 45-mm thick strips inter-connected with a toothed joint and with the medullas of the outer plies facing outwards. 
Cada uno de los pares presentaba una de sus testas cortada en dos planos, con objeto de permitir un buen apoyo de la probeta en el banco de ensayos. En el otro extremo se había practicado un cajeado para permitir la inserción de los elementos de unión. La sección de todas las cajas era idéntica, mientras que la anchura tenía dos posibles magnitudes, $20 \mathrm{~mm}$ y $5 \mathrm{~mm}$ (Figura 2), según el tipo de elemento de unión a introducir. Además, todas las piezas contaban con dos taladros pasantes idénticos de $\varnothing 13 \mathrm{~mm}$, que atravesaban cada una de las cajas para permitir la introducción de los pernos roscados.

Los dos pares que constituyen cada dintel se unen en la cumbre introduciendo en los cajeados uno de los dos posibles elementos de unión a comparar, previamente taladrados. La conexión entre la pieza de unión y los pares se realiza mediante cuatro pernos roscados M12x120 mm con tuercas y arandelas, que se aprietan mediante una llave dinamométrica a un par uniforme de $20 \mathrm{Nm}$.
One of the ends of each rafter was notched to better secure the specimen to the test bench. A groove was cut into the other end to house the truss plates or inserts. The height and length of the grooves were the same in all the specimens, but in three the width was $20 \mathrm{~mm}$ and $5 \mathrm{~mm}$ in the other three (Figure 2), depending on the type of element to be housed. All the rafters had two identical 13-mm $\varnothing$ drill holes across the grooves to house threaded bolts.

The two rafters forming each member were joined at the ridge by inserting the steel truss plate or plywood bracket into the grooves. Holes were drilled into both before insertion. The truss plates were joined to the rafters with four M12x120 threaded bolts consisting in screws and washers, tightened with a torque wrench set for a uniform torque of $20 \mathrm{Nm}$.
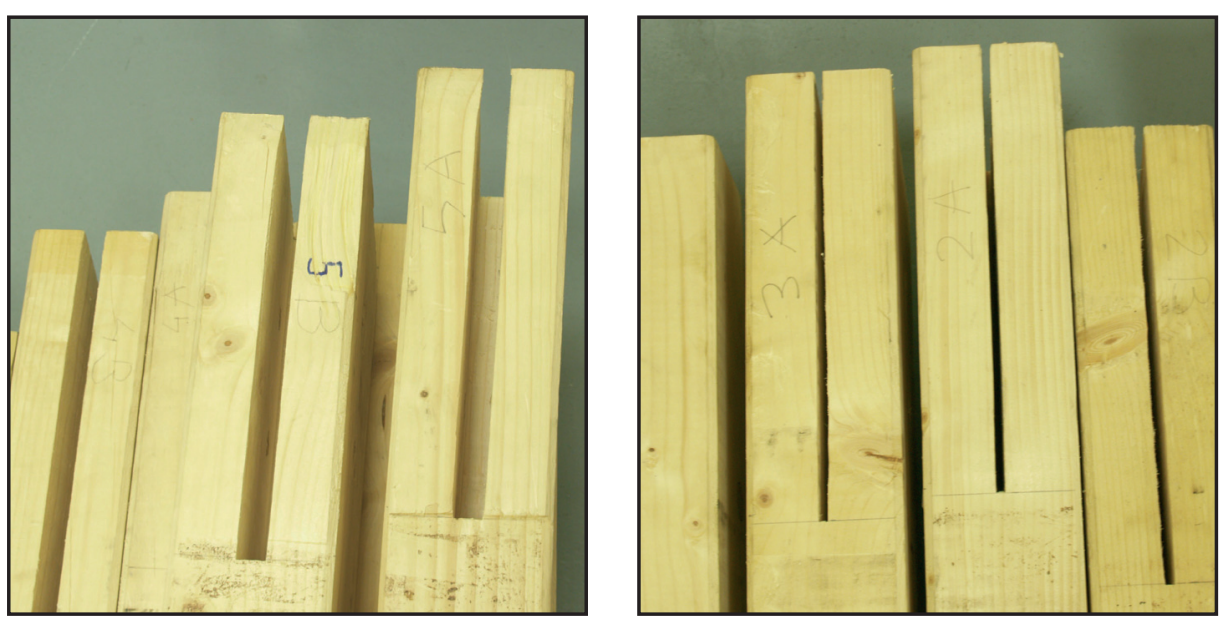

Figura 2. Cajeados para unión con pieza de contrachapado y con herraje metálico. Figure 2. Grooves for birch plywood inserts and steel truss plates.

Los elementos de unión estudiados presentaban geometría similar, pero grosor y materiales distintos:

3 piezas en forma de $\mathrm{V}$ con un ángulo de $144^{\circ}$, correspondiente a la pendiente de cubierta de $18^{\circ}, 300 \mathrm{~mm}$ de lado, $120 \mathrm{~mm}$ de canto y esquinas achaflanadas, fabricadas a partir de tablero contrachapado de abedul de $18 \mathrm{~mm}$ de espesor, con trece chapas y doce líneas de cola. Estas piezas disponían de cuatro taladros pasantes de $\varnothing 13 \mathrm{~mm}$ situados a $94 \mathrm{~mm}$ del borde y a la misma distancia entre los centros de los agujeros. Las propiedades mecánicas se obtuvieron de la norma EN 789:04 (6).

3 piezas metálicas de acero S275, sin tratamiento frente a la corrosión, también en forma de $\mathrm{V}$, mismo ángulo,
While the geometry of the truss plates and inserts studied was similar, their thickness and constituent materials varied:

Three $V$-shaped inserts with an angle of $144^{\circ}$ to form a roof with an $18^{\circ}$ slope. These inserts were $300 \mathrm{~mm}$ long on each side and $120 \mathrm{~mm}$ high, had bevelled corners and were made from 18- $\mathrm{mm}$ thick birch plywood with thirteen plies and twelve layers of glue. They had four 13-mm $\varnothing$ drill holes, each outer hole at $94 \mathrm{~mm}$ from the edge and likewise at $94 \mathrm{~mm}$, centres, from the adjacent inner hole. The mechanical properties were taken from European standard EN 789:04 (6).

Three truss plates made of S275 steel with no anticorrosion treatment, likewise $V$-shaped, with the same 
taladros y dimensiones de las otras piezas con la excepción del espesor de sólo $4 \mathrm{~mm}$.

\subsection{Equipos de ensayo}

Para llevar a cabo los ensayos de resistencia de los pórticos se utilizó un marco universal dispuesto en posición horizontal para facilitar la ejecución de los ensayos, constituido por un entramado modular a base de perfiles HEB cuyas alas superiores presentan múltiples taladros permitiendo una gran versatilidad en cuanto a dimensiones de las piezas y posibilidades de colocación.

Para materializar los vínculos de los pórticos a ensayar se dispusieron unas piezas de acero de gran rigidez en forma de angular con rigidizadores transversales que se atornillan al marco en la posición deseada.

El sistema de aplicación de las fuerzas se encomendó a una célula de carga tipo MTS Modelo 661.22 D-01 y a un émbolo de carga MTS Serie 243, Modelo 243.30, con capacidad para aplicar 253 kN en compresión y 162 kN en tracción, con un recorrido máximo del pistón de 508 mm.

La versatilidad del marco de ensayo permite fijar mecánicamente el émbolo de carga en la posición que se precisa. El empuje del pistón actúa sobre una viga de acero de perfil HEB que transmite a su vez, a través de unos rodillos separados $705 \mathrm{~mm}$, las dos cargas puntuales que solicitaron a los pórticos en el ensayo programado de flexión en cuatro puntos (Figura 3). angle, drill holes and dimensions as the plywood inserts, with the exception of the thickness, which was just $4 \mathrm{~mm}$.

\subsection{Test equipment}

The members were strength tested on a universal load frame in a horizontal position to facilitate testing. This versatile load frame consisted in a modular lattice made of wide flange beams whose top flanges contained numerous holes for attaching specimens of different sizes and in different positions.

The rafter assemblies were attached to the frame using very stiff, angular steel elements and transverse stiffeners that were bolted to the frame in preestablished positions.

The force was applied with an MTS Model 661.22 D-01 load cell and an MTS Series 243, Model 243.30 loading piston with a maximum travel length of $508 \mathrm{~mm}$ and a maximum capacity of $253 \mathrm{kN}$ (compression) and $162 \mathrm{kN}$ (tension).

Thanks to the versatility of the frame, the loading piston could be positioned as needed. The piston thrust was transferred to a wide flange steel beam, which in turn transferred the point loads to the specimens across rollers spaced at 705- $\mathrm{mm}$ intervals, in accordance with the four-point bending test programme (Figure 3).

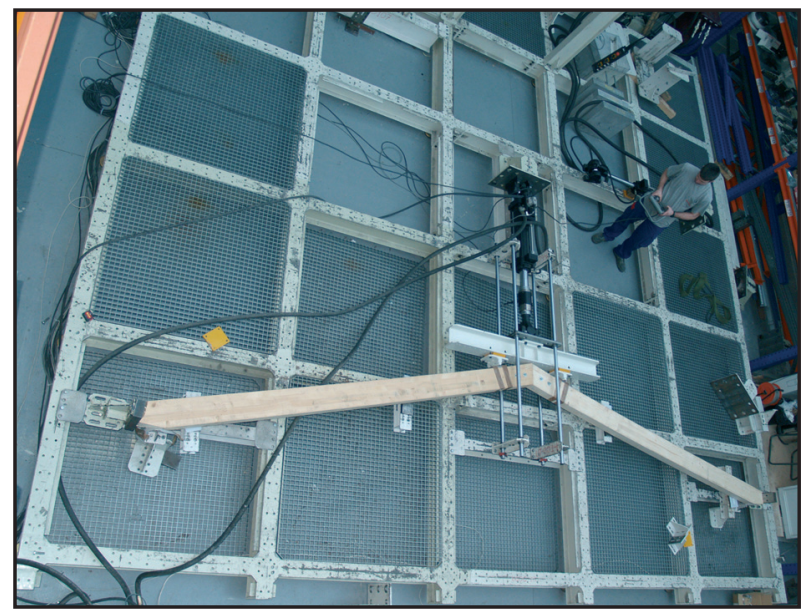

Figura 3. Vista general del montaje del pórtico durante un ensayo. Figure 3. Overview of the specimen during the test.

Los movimientos del pórtico ensayado en el sentido de la carga se registraron mediante un dispositivo situado en la parte inferior de éste, bajo la cumbrera, capaz de medir los desplazamientos de modo continuo con una precisión de $1 \mathrm{~mm}$.
Specimen movements in the direction in which the load was applied were recorded by a device positioned on the under side of the ridge, able to measure movements with a precision of up to $1 \mathrm{~mm}$. 
En varios momentos (recepción de piezas, montaje de pórtico y antes y después de los ensayos) se tomaron lecturas de la temperatura y humedad del aire ambiente mediante un termohigrómetro y de las propias piezas mediante un xilohigrómetro de electrodos. Estos datos se recogen en la Tabla 1.

\subsection{Procedimiento de ensayo}

Se llevaron a cabo un total de 6 ensayos a escala real, tres sobre pórticos con inserto de herraje metálico y tres en pórticos con inserto de contrachapado, sometiendo a las piezas ya descritas a una flexión en cuatro puntos según un protocolo de carga que más adelante se detalla.

Se comenzó obteniendo las dimensiones de los pares, midiendo la longitud del mayor paralelepípedo inscrito en cada una de las escuadrías, así como la distancia entre los puntos medios de la superficie de apoyo de las probetas. Para la anchura, se midió la anchura en dirección perpendicular al eje longitudinal de la pieza en tres puntos diferentes. Todos los puntos de medida estaban libres de defectos. El espesor se midió asimismo en tres puntos libres de defectos en dirección perpendicular a la cara. Dada la nula trascendencia en el ensayo, no se comprobaron las tolerancias dimensionales.

Posteriormente se determinó el contenido de humedad de las piezas, mediante xilohigrómetro de electrodos, en tres puntos de cada una de las caras. Las lecturas se efectuaron siempre a distancia superior a $1 \mathrm{~m}$ de los extremos de todas las escuadrías, y en el centro de las mismas. El área de medida estaba exenta de madera resinosa y de singularidades tales como corteza, nudos, entrecasco, etc. En todos los casos la penetración de las puntas fue la correspondiente a 1/3 del espesor de la pieza, corrigiéndose en su caso las lecturas obtenidas mediante las tablas correspondientes con que cuenta el equipo de medida, de acuerdo con la especie y la temperatura de las secciones. Se consideró como \% de humedad, la media aritmética de todas las lecturas de cada pieza.

A continuación se procedió a ensayar a resistencia los seis dinteles según la norma UNE-EN 595:96.1996 "Estructuras de madera. Ensayo para la determinación de la resistencia y rigidez de las cerchas" (7). El objeto de este ensayo es determinar la resistencia de los elementos de cubierta de madera aserrada o madera laminada encolada. El ensayo bajo carga uniformemente distribuida se ha simulado mediante un ensayo a flexión en cuatro puntos, tal y como admite la norma anterior. La magnitud de las dos cargas puntuales se determina para que proporcionen el mismo momento flector máximo en los pares que alcanzarín con las cargas reales que deberá soportar la cubierta.
Ambient air temperature and humidity and the temperature and humidity of the timbers themselves were measured respectively with a thermohygrometer and an electrode-fitted wood moisture meter at various times throughout the process (receipt of the material, upon specimen assembly and before and after testing). These data are given in Table 1.

\subsection{Test procedure}

A total of six full-scale tests were conducted, three with rafter pairs joined with a steel fitting and the other three with a plywood insert. All were subjected to four-point bending as described below.

The first step was to measure the rafters, namely the cross-section (the larger parallelepiped) and the distance, centres, between the two supports. The width was measured perpendicular to the long axis at three flawless points. Thickness was likewise measured at three flawless points, perpendicular to the front side. In light of its irrelevance to the test, dimensional tolerance was not verified.

Specimen moisture was determined at three points on each side with a wood moisture meter fitted with electrodes. All readings were taken at a distance of over $1 \mathrm{~m}$ from the ends and at the middle of the crosssection. The areas measured were free of resinous wood and other heterogeneities such as bark, knots, bark pockets and so on. In all cases the pins penetrated to a depth equal to $1 / 3$ of the timber thickness and the readings obtained were corrected for species and wood temperature in accordance with the tables built into the instrument. The moisture percentage was regarded to be the arithmetic mean of all the readings for each timber.

The six specimens were then tested for strength as stipulated in standard UNE-EN 595:96.1996 "Timber structures - Test methods - Test of trusses for the determination of strength and deformation behaviour" (7). The purpose of this test is to determine the strength of solid wood or plywood roof members. Pursuant to the specifications laid down in the aforementioned standard, a uniformly distributed load was simulated with fourpoint bending. The magnitude of the two point loads was defined as the load that would generate the same maximum bending moment on the rafters that they would have to withstand in an actual roof. 
Sobre el marco se colocaron un par de apoyos a la separación de $6 \mathrm{~m}$, mecánicamente unidos a éste, para sujetar ambos extremos del pórtico de modo que impidieran sus desplazamientos en el plano horizontal. De este modo se simulaba, con suficiente aproximación, la puesta en obra real de los pares de cubierta sobre el zuncho perimetral de hormigón donde apoya. Seguidamente se dispuso el pórtico a ensayar en posición horizontal sobre el marco, calzado y nivelado para que la carga fuera aplicada en el plano medio del pórtico. Para evitar flexiones por peso propio en el plano transversal al de la carga, se colocaron unos apoyos metálicos. Asimismo se dispusieron perfiles metálicos en la parte superior de cada par a la mitad de su luz, que actuaron como puntos de arriostramiento transversal para evitar desplazamientos fuera del plano de la carga. Todas las superficies de contacto metal-madera llevaban interpuesta una lámina de teflón, reduciendo al mínimo el efecto del rozamiento.

Para evitar que se produjese un aplastamiento local bajo los rodillos que cargaban los pórticos, se dispuso entre éstos y la pieza de madera unos forros de chapa metálica de $120 \times 100 \times 15$ mm, además de una lámina de teflón entre el propio forro y el par, evitando así efectos de rozamiento.

Para determinar la resistencia de la estructura de madera, la norma UNE-EN 595:1996 define un procedimiento de ensayo en dos fases, cada una de ellas de acuerdo con el siguiente protocolo:

10) Tras la puesta a cero se carga la estructura a una velocidad de $35 \mathrm{~N} / \mathrm{s}$ hasta un valor equivalente a la acción permanente que deberá soportar en servicio la estructura que se estimó en 18 kN correspondientes a una carga permanente superficial (peso propio de la cubierta) de $1 \mathrm{kN} / \mathrm{m}^{2}$ y considerando una separación entre pórticos de $3 \mathrm{~m}$.

$\left.2^{\circ}\right)$ Se hace una parada manteniendo la carga constante durante $1.800 \mathrm{~s}$ tomando lectura de deformaciones.

30) Se lleva a cabo una descarga total $(F=0)$ tomando lectura continua también de las deformaciones.

40) Se mantiene durante un tiempo de $900 \mathrm{~s}$ la carga a cero y se toma lectura de las deformaciones. En este punto concluye la denominada fase inicial de carga, para dar paso a la denominada fase de resistencia.

$\left.5^{\circ}\right)$ Se vuelve a aplicar la carga a la velocidad de $35 \mathrm{~N} / \mathrm{s}$ hasta un valor equivalente a la suma de la acción permanente más las acciones variables (se adoptó una carga variable superficial total de $1,5 \mathrm{kN} / \mathrm{m}^{2}$ ) que deberá soportar en servicio la estructura estimada en $45 \mathrm{kN}$.

$\left.6^{\circ}\right)$ Una vez alcanzados los $45 \mathrm{kN}$ se hace una nueva parada, manteniendo la carga en este nivel durante un periodo de $900 \mathrm{~s}$ tomando lectura de deformaciones.

70) Finalmente se procede a aumentar la carga a la misma velocidad anterior, hasta llegar a la rotura. Los
Two supports were mechanically attached to the frame at a distance of $6 \mathrm{~m}$ to secure the two ends of the specimen and prevent any horizontal displacement. This arrangement provided for a sufficiently approximate simulation of the actual positioning of roof rafters on the concrete tie beam on which they rest. The structure was then tested in a horizontal position after due levelling to ensure that the load was applied along its mid-plane. Steel supports were used to prevent self weight-induced bending in the plane transverse to the loading plane. Steel shapes were also placed on the top side of each rafter at mid-span to act as transverse bracing to prevent movements outside the loading plane. All the steel-wood interfaces were fitted with a Teflon membrane to reduce friction to a minimum.

Steel plate liners measuring $120 \times 100 \times 15 \mathrm{~mm}$, as well as a Teflon membrane between the liner and the rafter to reduce friction, were positioned under the rollers to prevent local collapse.

Standard UNE-EN 595:1996 defines a two-stage test procedure to determine structural timber strength in accordance with the following protocol:

10) After load zeroing, the structure was loaded at a rate of $35 \mathrm{~N} / \mathrm{s}$ to a value equivalent to the permanent load that it would support when in service, which was estimated to be $18 \mathrm{kN}$. This in turn was calculated to correspond to a surface load (roof self weight) of $1 \mathrm{kN} / \mathrm{m}^{2}$, assuming the rafters to be spaced at 3-m intervals.

$\left.2^{\circ}\right)$ The specimen was subjected to the aforementioned maximum load for $1800 \mathrm{~s}$ to measure deformation.

30) The load was ramped down to $F=0$, while continuous deformation readings were taken.

40) After $900 \mathrm{~s}$ at zero load, deformation readings were taken. This was the transition step between the socalled initial and strength stages.

50) The structure was re-loaded at a rate of $35 \mathrm{~N} / \mathrm{s}$ to a value equivalent to the sum of the permanent load + live loads (a total live surface load of $1.5 \mathrm{kN} / \mathrm{m}^{2}$ was assumed) to be withstood by the structure, estimated to be $45 \mathrm{kN}$.

60) A 45-kN load was maintained for $900 \mathrm{~s}$ to measure deformation.

70) Finally, the loaded was increased at the aforementioned rate until the specimen failed. 
ensayos se llevaron a cabo en control de carga hasta la última meseta, pasando a partir de este momento a un control de desplazamiento.

Se considera que se ha alcanzado la carga máxima de la estructura $F_{\max }$ cuando se produce la rotura de cualquier parte o de la unión de la misma, o bien se produce una fuerte deformación sin aumento de la carga transmitida.

La Figura 4 muestra dos gráficos simultáneos generados directamente por la máquina de ensayos, que representan, frente al tiempo (s), la carga (N) y los desplazamientos $(\mathrm{mm})$ en una pieza.
After the last plateau, testing was monitored in terms of displacement rather than load.

The ultimate load, $F_{\text {max }}$ was defined to be the load at which the joint or any other part of the structure failed, or at which severe deformation took place with no increase in load.

Figure 4 shows two simultaneous graphs generated directly by the load frame, in which load ( $N$ ) and displacement $(\mathrm{mm})$ are plotted against time $(\mathrm{s})$.

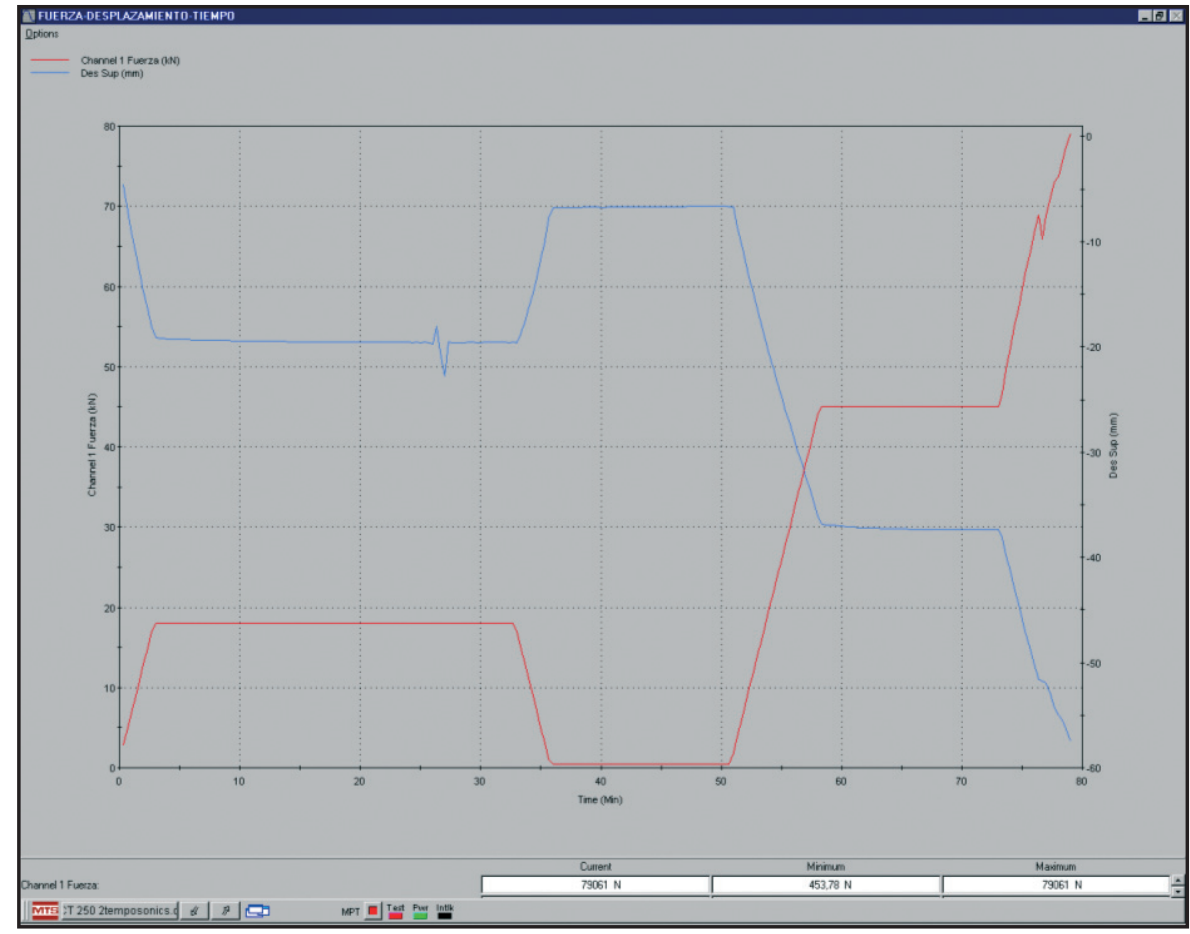

Figura 4. Gráficos carga-tiempo y desplazamiento-tiempo para el protocolo de ensayo. Figure 4. Load-time and displacement-time graphs for the test protocol.

\section{RESULTADOS Y DISCUSIÓN}

Para cada una de las seis estructuras ensayadas según el protocolo descrito, se registraron a intervalos de $2 \mathrm{~s}$ los valores de carga aplicada y de desplazamiento del nudo en el plano de la carga, lo que permitió disponer de una gran cantidad de datos. Los más relevantes se incluyen en modo gráfico en las Figuras 5 y 6 . Estas dos figuras representan, respectivamente para las tres piezas que incorporan el tradicional inserto metálico y para las tres piezas en las que se optó por la pieza de contrachapado de abedul, las curvas carga (N) - desplazamiento $(\mathrm{mm})$.

\section{RESULTS AND DISCUSSION}

The loads applied and node displacements in the loading plane were recorded at 2-s intervals for all six structures tested, generating a large volume of data. The most relevant of these are depicted in Figures 5 and 6. These two figures respectively show the load $(\mathrm{N})$ - displacement $(\mathrm{mm})$ curves for the three specimens joined with a traditional steel truss plate and the three bearing a birch plywood insert. 
Carga (N) - Desplazamiento (mm). Pieza $\mathrm{n}^{\circ} 1 /$ Load (N) - Displacement (mm). Specimen $n^{\circ} 1$

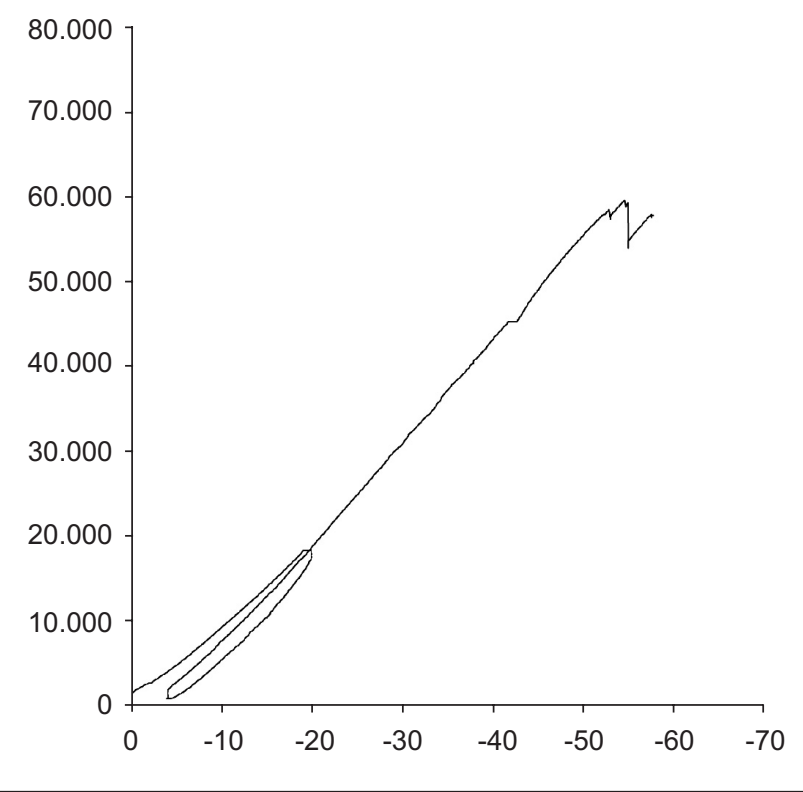

Carga (N) - Desplazamiento (mm). Pieza $\mathrm{n}^{\circ} 2$ / Load (N) - Displacement (mm). Specimen $n^{\circ} 2$

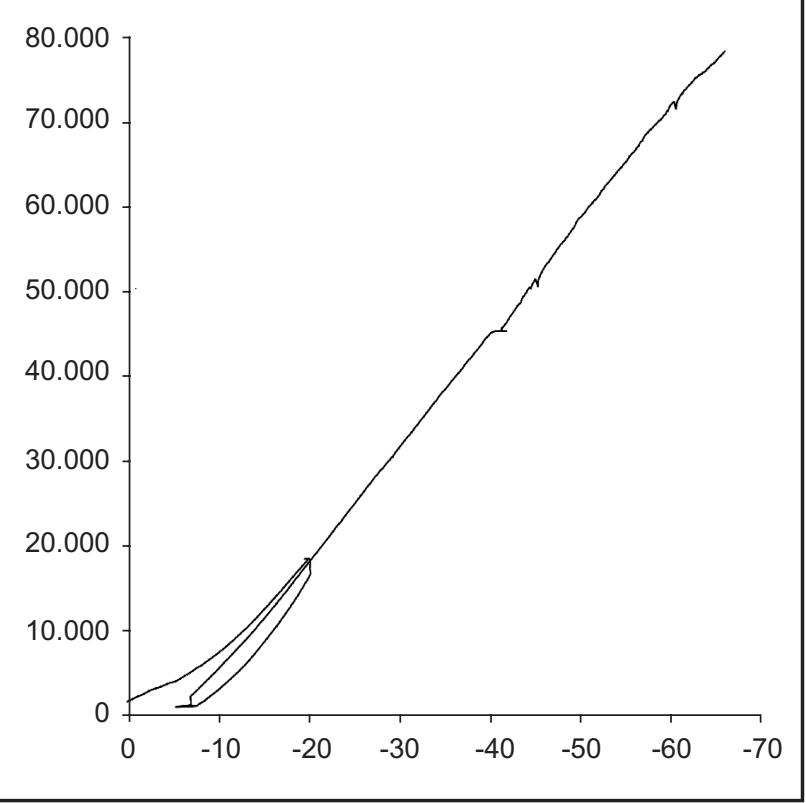

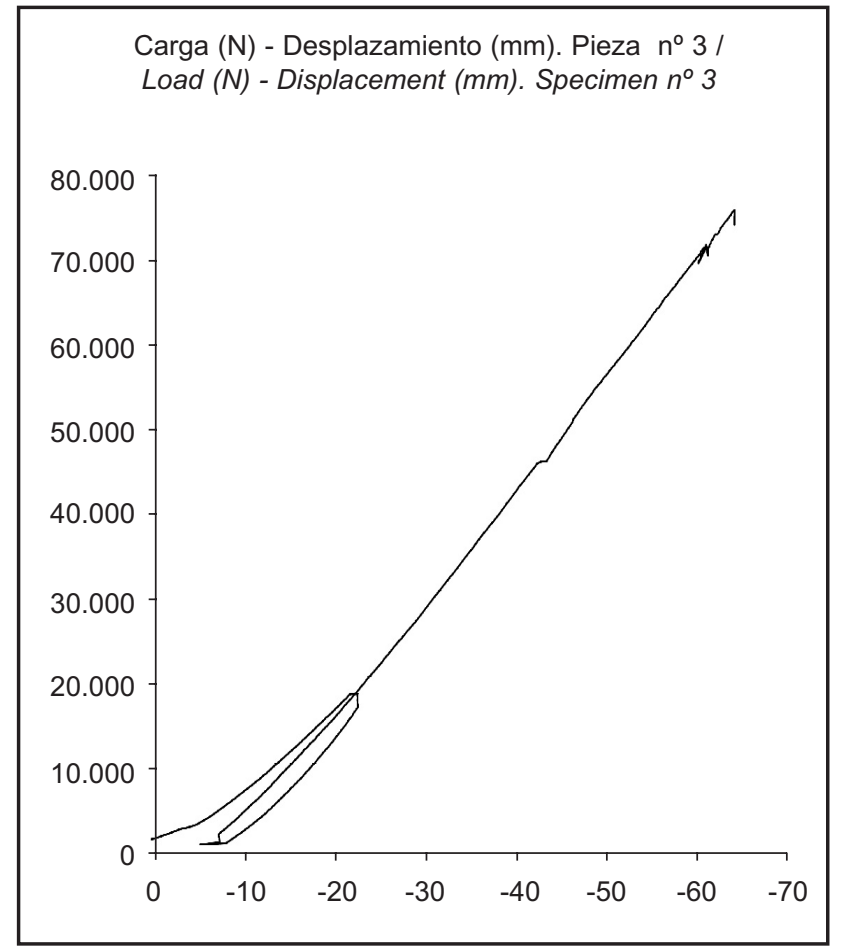

Figura 5. Curvas carga-desplazamiento para las 3 piezas con unión de inserto metálico.

Figure 5. Load-displacement curves for three specimens joined with a truss plate.

En todas las curvas correspondientes a las piezas individuales se puede observar el bucle provocado por las fases de carga inicial, meseta, descarga y posterior carga hasta la rotura pasando por una nueva meseta. Cabe destacar, en primer lugar, que los resultados muestran una buena capacidad portante de la estructura
The loop on the individual curves reflects initial loading, plateau, unloading and rise to the first plateau, followed by subsequent loading to failure after the final plateau. The findings show, firstly, that the structure tested exhibited high bearing capacity, which in all cases amply exceeded the maximum service load under normal 

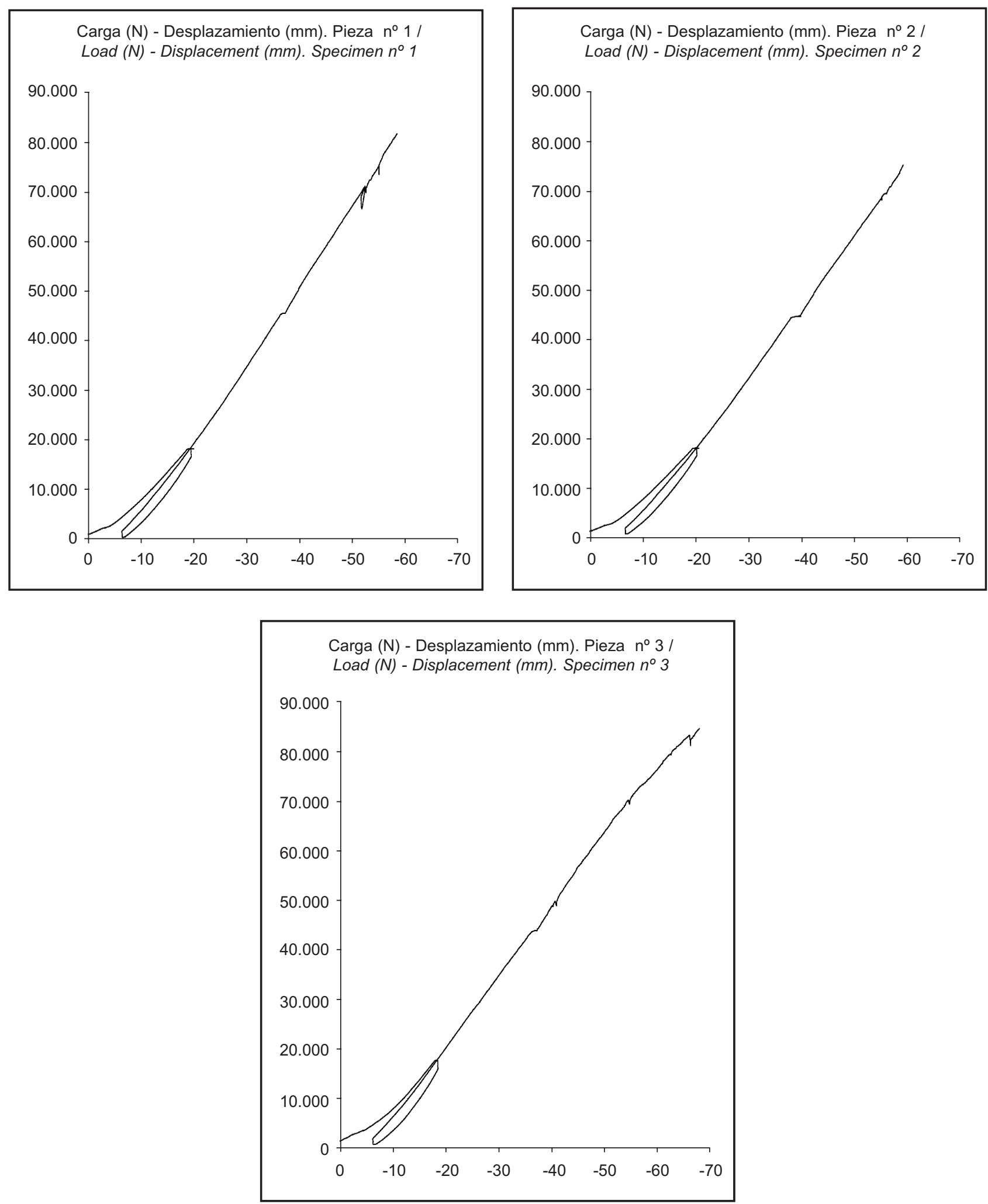

Figura 6. Curvas carga-desplazamiento para las 3 piezas con unión de tablero contrachapado.

Figure 6. Load-displacement curves for three specimens joined with a plywood insert.

ensayada, excediendo con holgura en todos los casos la carga máxima prevista de servicio que se había estimado en $45 \mathrm{kN}$, definida a partir del cálculo para un estado habitual de carga según el Eurocódigo 5 (8) y el conditions, estimated to be $45 \mathrm{kN}$ based on Eurocode 5 (8) and Spanish Technical Building Code (9) specifications. The lowest ultimate load recorded, in fact, was $60 \mathrm{kN}$ (specimen 1 with a steel fitting), while all the 
Código Técnico de Edificación (9). De hecho se alcanzó un valor de carga máxima próximo a los $60 \mathrm{kN}$ en el peor caso (pieza no 1 con herraje metálico), superándose los $74 \mathrm{kN}$ en el resto de situaciones y rebasando incluso los $85 \mathrm{kN}$ en el mejor de los casos (pieza no 3 con tablero contrachapado). La Tabla 1 recoge los valores máximos y medios de las dos series, así como el contenido de humedad de las piezas $(\mathrm{CH})$, la temperatura ambiente ( $\mathrm{T}^{\mathrm{a}}$ ) y la humedad relativa del laboratorio (HR). Asimismo y para tener una idea del valor de agotamiento y de la rigidez se incluyen la tensión máxima aproximada de flexión en los pares cuando se alcanza la carga máxima y un parámetro de rigidez (Fuerza/Desplazamiento). other specimens failed at over $74 \mathrm{kN}$ and the best result, found for specimen 3 with a plywood insert, was upward of $85 \mathrm{kN}$. Table 1 gives the maximum and mean values for the two series, along with specimen moisture content (MC) and the laboratory temperature $(T)$ and relative humidity $(\mathrm{RH})$. The table also shows the approximate maximum stress on the rafters at ultimate load and a stiffness parameter (load/displacement).

Tabla 1 / Table 1

Valores de carga y tensión máxima, rigidez, $\mathrm{CH}$ de piezas, de temperatura y HR del laboratorio. Ultimate load, maximum stress, stiffness, specimen $M C$, laboratory temperature and $R H$.

\begin{tabular}{|c|c|c|c|c|c|c|c|c|}
\hline & \multicolumn{4}{|c|}{$\begin{array}{l}\text { Piezas con herraje metálico / } \\
\text { Specimens with steel fitting }\end{array}$} & \multicolumn{4}{|c|}{$\begin{array}{l}\text { Piezas con tablero contrachapado / } \\
\text { Specimens with plywood insert }\end{array}$} \\
\hline & N01 & $\mathrm{N} 02$ & $\mathrm{~N}^{03}$ & Media / Mean & $\bar{N} \mathbf{N}_{1}$ & $\mathrm{~N} 02$ & N03 & Media / Mean \\
\hline Carga máx. / Ult. load & $59.03 \mathrm{kN}$ & $78.06 \mathrm{kN}$ & $74.29 \mathrm{kN}$ & $70.46 \mathrm{kN}$ & $80.78 \mathrm{kN}$ & $75.97 \mathrm{kN}$ & $85.55 \mathrm{kN}$ & $80.77 \mathrm{kN}$ \\
\hline Tensión máx. / Max. stress & $16.8 \mathrm{MPa}$ & $22.2 \mathrm{MPa}$ & $21.2 \mathrm{MPa}$ & $20.1 \mathrm{MPa}$ & $23 \mathrm{MPa}$ & $21.7 \mathrm{MPa}$ & $24.4 \mathrm{MPa}$ & $23 \mathrm{MPa}$ \\
\hline Rigidez $(F / \delta) /$ Stiffness $(F / \delta)$ & $1029 \mathrm{~N} / \mathrm{mm}$ & $1120 \mathrm{~N} / \mathrm{mm}$ & $1048 \mathrm{~N} / \mathrm{mm}$ & $1066 \mathrm{~N} / \mathrm{mm}$ & $1235 \mathrm{~N} / \mathrm{mm}$ & $1136 \mathrm{~N} / \mathrm{mm}$ & $1279 \mathrm{~N} / \mathrm{mm}$ & $1217 \mathrm{~N} / \mathrm{mm}$ \\
\hline $\mathrm{CH}$ piezas / Spec. MC & $9.6 \%$ & $10.1 \%$ & $10.2 \%$ & $10.1 \%$ & $9.1 \%$ & $11.4 \%$ & $10.6 \%$ & $10.4 \%$ \\
\hline $\mathrm{T}^{\mathrm{a}}$ y HR (lab.) / T, RH (lab.) & $\begin{array}{l}18.4{ }^{\circ} \mathrm{C} \\
56.1 \%\end{array}$ & $\begin{array}{l}19.6^{\circ} \mathrm{C} \\
51.8 \%\end{array}$ & $\begin{array}{l}19.4^{\circ} \mathrm{C} \\
50.8 \%\end{array}$ & $\begin{array}{c}19.1^{\circ} \mathrm{C} \\
52.9 \%\end{array}$ & $\begin{array}{c}20.2^{\circ} \mathrm{C} \\
46.8 \%\end{array}$ & $\begin{array}{c}19.9^{\circ} \\
\text { C44.8\% }\end{array}$ & $\begin{array}{l}17.6^{\circ} \mathrm{C} \\
49.6 \%\end{array}$ & $\begin{array}{l}19.2^{\circ} \mathrm{C} \\
47.1 \%\end{array}$ \\
\hline
\end{tabular}

Todas las piezas ensayadas, tanto si se empleaba una unión mediante herraje metálico como si se hacía a partir de contrachapado de abedul, mostraron en términos generales una respuesta muy similar, con un comportamiento prácticamente lineal hasta la rotura y unas rigideces casi idénticas. Es importante también destacar la más que aceptable repetibilidad de los datos en cada una de las series, aval de una buena representabilidad de los mismos.

Durante los tanteos iniciales se pudo constatar que resulta imprescindible restringir los movimientos horizontales de los apoyos en el sentido perpendicular al eje de la carga, tal y como se aplica en la realidad. De no ser así, se produce una rápida abertura del nudo en la parte inferior (parte traccionada) que obliga que sea la pieza del inserto la que transmita la tracción y en el caso de utilizar el tablero contrachapado la rotura se alcanzaría de forma súbita y para una carga considerablemente más baja de las cargas alcanzadas en la situación del ensayo. Como consecuencia de lo anterior y a pesar de las grandes deformaciones registradas la transmisión de los esfuerzos en el nudo de cumbrera se realizó fundamentalmente por contacto entre las testas de los pares en lugar de hacerlo a través de las placas.
All the specimens tested, whether joined with a steel fitting or a plywood insert, exhibited similar patterns: nearly linear behaviour to failure and practically identical stiffness values. Note the high repeatability of the data in both series, an endorsement of their representativeness.

The initial or pre-trials showed that to accurately simulate real conditions, horizontal movement at the supports, perpendicular to the loading plane, must be constrained. Otherwise, as a result of the very early stage separation of the rafters at the under side of the node (subjected to tensile stress), the tensile stress must be transferred across the insert or truss plate. Under these circumstances, failure would be reached abruptly in the specimens joined by a plywood insert, at a considerably lower load than recorded during the test. Consequently, despite the substantial deformation recorded, thanks to the constraint imposed, forces on the ridge node were transferred essentially across the contact between the two rafters instead of across the plate or insert. 
También se observó una repetibilidad en los modos de rotura. La mayoría de fallos se produjeron por la zona de los taladros (Figura 7 izquierda), progresando hasta conectar los dos taladros contiguos de uno de los pares. Además pero con posterioridad al primer modo, se observó un segundo fallo en la cumbrera, al acuñarse las láminas superiores de cada pieza, una vez que los desplazamientos eran ya muy notables.

En uno de los casos ensayados se produjo una rotura por flexión aproximadamente en la zona central de uno de los pares (Figura 7 derecha). La disparidad de este modo de fallo en relación con los presentes en las otras piezas quedó aclarada al analizar con detalle la sección de la escuadría: exactamente en la zona fracturada se detectó la coincidencia de dos grandes nudos ocultos en las láminas interiores. En uno de ellos incluso se observaba la presencia parcial de su rama correspondiente y entrecasco, afectando a una parte importante de su sección resistente. Este defecto observado puede considerarse que invalida el ensayo de esta pieza, por cuanto puede contravenir los requisitos de fabricación de las láminas establecidos en la norma UNE-EN 385:2002 (10).
Repeatability was also observed for the failure modes. Most failures were located at the drill holes (Figure 7, left), where cracking ultimately connected two adjacent holes in one of the rafters. In addition but subsequent to this first type of failure, a second type was observed, also at the ridge, where the top layers in each rafter had been wedged open after considerable displacement had taken place.

In one specimen, bending failure was observed at approximately mid-span of one of the rafters (Figure 7, right). The discrepancy between this failure mode and the findings for all the other specimens was clarified when the cross-section was analyzed: two large knots, concealed in the inner layers, were detected in exactly the area that failed. In one, part of the respective branch and bark pocket were observed to be present and involve a substantial proportion of the bearing section. This flaw may be regarded to invalidate the test on this specimen, inasmuch as it may constitute an infringement of the manufacturing requirements laid down in standard UNE-EN 385:2002 (10).

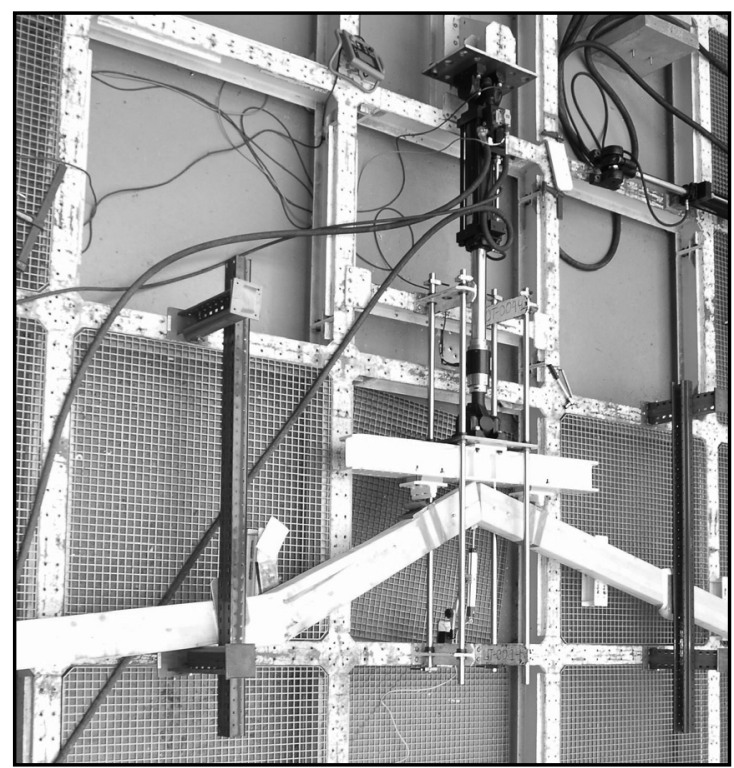

Figura 7. Diversos modos de rotura observados en los ensayos. Figure 7. Failure modes observed during the tests.

También se observaron en ocasiones grietas en las zonas de tracción que progresaban hacia los apoyos y que en algún caso provocaron una delaminación de la pieza por su parte inferior.

En cuanto a los elementos de unión empleados se pudo observar, una vez desmontada la estructura, que el daño presente no era muy apreciable, independientemente del tipo de pieza utilizada. Tan sólo pequeños aplastamientos en el contorno del taladro por su contacto con el perno roscado.
Occasional cracks in the areas under tensile stress were observed to advance toward the supports and in some cases cause scaling on the underside.

The structures were dismounted to examine the joint pieces for damage, which was barely perceptible in both truss plates and plywood inserts and limited to minor crushing around the drill hole due to contact with the threaded bolt. 


\section{CONCLUSIONES}

A partir de las observaciones y los datos recogidos en los ensayos que se han descrito, pueden extraerse las siguientes conclusiones:

En primer lugar mencionar que los elementos de cubierta ensayados, tanto si emplean el nuevo sistema de unión propuesto como si incluyen el tradicional herraje metálico, son capaces de soportar perfectamente los esfuerzos a los que se encuentran sometidos, de acuerdo con las condiciones de servicio habituales en este tipo de estructuras.

Se ha constatado el hecho de que la sustitución de la pieza de herraje metálico por otra de geometría similar, elaborada a partir de tablero contrachapado de abedul, no solamente abarata los costes, hace más flexible su fabricación y simplifica el montaje, sino que no representa ninguna disminución en la capacidad portante del conjunto de la estructura ensayada, lo que supone satisfacer el objetivo principal que se pretendía con este trabajo.

Se debe tener en cuenta que la concentración de singularidades en la madera, así como la coincidencia de nudos, puede originar un modo agotamiento menos previsible y súbito que el mostrado por la estructura de forma generalizada. En general la rotura se inicia en la zona de los taladros y da lugar a grietas que progresan de modo muy apreciable antes de producirse el colapso final.

Los resultados del presente estudio son aplicables a las uniones en cumbrera de secciones de madera maciza o laminada de uso estructural, empleadas en la construcción de cubiertas, siempre que las solicitaciones se mantengan en el plano de la estructura.

\section{AGRADECIMIENTOS}

Los autores de este trabajo desean expresar su gratitud por un lado a la empresa Maderas Pisuerga, S.L., que amablemente nos proporcionó todas las piezas a ensayar y, por otro lado, a la empresa Esmena, S.A., por su desinteresada colaboración, permitiéndonos utilizar sus instalaciones y equipos de ensayos del Parque Científico y Tecnológico de Gijón sin los cuales no habría sido posible desarrollar este trabajo.

\section{CONCLUSIONS}

The conclusions to be drawn from the observations and data described in the foregoing are as follows:

First of all, the roof members tested, whether joined by the new type of insert proposed or by traditional steel fittings, are perfectly able to withstand the loads to which they are subjected under normal service conditions for these structures.

Replacing the steel fitting with a similarly shaped birch plywood insert not only lowers costs, renders manufacture more flexible and simplifies assembly, but it forfeits no bearing capacity in the structure tested, thereby covering the main objective pursued in this study.

The concentration of heterogeneities in the wood, along with the concurrence of knots, may generate less foreseeable and more abrupt collapse than observed in the structure as a whole. As a rule, failure begins around the drill holes, giving rise to cracks that advance very perceptibly before final collapse.

The present findings are applicable to ridge joints in solid or laminated structural timber used in roof construction, providing the load is maintained within the plane of the structure.

\section{ACKNOWLEDGEMENTS}

The authors wish to express their gratitude to Maderas Pisuerga, S.L., which kindly provided the materials tested, and Esmena, S.A., for its generous collaboration, including the use of their testing facilities and equipment at the Parque Científico y Tecnológico de Gijón, without which this study would not have been possible.

\section{BIBLIOGRAFÍA / BIBLIOGRAPHY}

(1) Arriaga, F.; Argüelles, R.: "Estructuras de Madera. Diseño y cálculo". AITIM (2000).

(2) Ross, P.; O. Arup.: "Appraisal and repair of timber structures". ASCE. Thomas Telford Ltd. (2002).

(3) Harada, M.; Hayashi, T.; Karube, M.; Lida A.; Komatsu, K.: "Static loading tests of glued laminated timber joints with drift pins. -The effect of MOE on anisotropy of mechanical property. Joints in timber structures". RILEM proceedings pro022 (2001). 
(4) Branco, J.; Cruz, P.; Piazza, M.; Varum, H.: "Experimental analysis of original and strengthened traditional timber connections". 9th World Conference on Timber Engineering. Portland (2006).

(5) Manual del contrachapado Finlandés. WISA, Lahtí. Finlandia (2006).

(6) EN 789:04. "Timber structures - Test methods - Determination of mechanical properties of wood based panels". CEN/TC 124 (2004).

(7) UNE-EN 595:96. "Estructuras de madera. Ensayo para la determinación de la resistencia y rigidez de las cerchas" (1996).

(8) EN 1995-1-1. "Eurocode 5: Design of timber structures. Part 1-1: General-Common rules and rules for buildings" (2004).

(9) CTE-DB SE-M. "Código Técnico de la Edificación. Documento Básico de Seguridad Estructural: Madera". Libro 6. Ministerio de Vivienda (2006).

(10) UNE-EN 385:02. "Empalmes por unión dentada en madera estructural. Especificaciones y requisitos mínimos de fabricación" (2002). 